\title{
Review \\ Cellular Therapy via Spermatogonial Stem Cells for Treating Impaired Spermatogenesis, Non-Obstructive Azoospermia
}

\author{
Nesma E. Abdelaal ${ }^{1}$, Bereket Molla Tanga ${ }^{2,3}{ }^{\text {, Mai Abdelgawad }}{ }^{4}$, Sahar Allam ${ }^{5} \mathbb{D}$, Mostafa Fathi ${ }^{6}$, \\ Islam M. Saadeldin ${ }^{7}$, Seonggyu Bang ${ }^{2}$ and Jongki Cho ${ }^{2, *(\mathbb{D})}$
}

1 Institute for Integrative Biology of the Cell (I2BC), CEA, CNRS, Universite Paris-Saclay/Île-de-France, 91198 Gif-sur-Yvette, France; nesma.elsayed-abdelaal-hassan@i2bc.paris-saclay.fr

2 College of Veterinary Medicine, Chungnam National University, Daejeon 34134, Korea; tanga@o.cnu.ac.kr (B.M.T.); bangsk97@o.cnu.ac.kr (S.B.)

3 Faculty of Veterinary Medicine, Hawassa University, P.O. Box 05 Hawassa, Ethiopia

4 Biotechnology and Life Sciences Department, Faculty of Postgraduate Studies for Advanced Sciences (PSAS), Beni-Suef University, Beni-Suef 62521, Egypt; maiAli@psas.bsu.edu.eg

5 Faculty of Medicine, Tanta University, Tanta 31527, Egypt; sahar30839688@med.tanta.edu.eg

6 Biotechnology Program, Faculty of Agriculture, Ain Shams University, Giza 11566, Egypt; mostafa.fathi61198@gmail.com

7 Department of Physiology, Faculty of Veterinary Medicine, Zagazig University, Zagazig 44519, Egypt; islamms@zu.edu.eg

* Correspondence: cjki@cnu.ac.kr; Tel.: +82-42-821-6788

check for updates

Citation: Abdelaal, N.E.; Tanga, B.M.; Abdelgawad, M.; Allam, S.; Fathi, M.; Saadeldin, I.M.; Bang, S.; Cho, J. Cellular Therapy via Spermatogonial Stem Cells for Treating Impaired Spermatogenesis, Non-Obstructive Azoospermia. Cells 2021, 10, 1779. https://doi.org/ 10.3390/cells10071779

Academic Editor: Darren Griffin

Received: 4 June 2021

Accepted: 12 July 2021

Published: 14 July 2021

Publisher's Note: MDPI stays neutral with regard to jurisdictional claims in published maps and institutional affiliations.

Copyright: (C) 2021 by the authors. Licensee MDPI, Basel, Switzerland. This article is an open access article distributed under the terms and conditions of the Creative Commons Attribution (CC BY) license (https:/ / creativecommons.org/licenses/by/ $4.0 /)$.
Abstract: Male infertility is a major health problem affecting about 8-12\% of couples worldwide. Spermatogenesis starts in the early fetus and completes after puberty, passing through different stages. Male infertility can result from primary or congenital, acquired, or idiopathic causes. The absence of sperm in semen, or azoospermia, results from non-obstructive causes (pretesticular and testicular), and post-testicular obstructive causes. Several medications such as antihypertensive drugs, antidepressants, chemotherapy, and radiotherapy could lead to impaired spermatogenesis and lead to a non-obstructive azoospermia. Spermatogonial stem cells (SSCs) are the basis for spermatogenesis and fertility in men. SSCs are characterized by their capacity to maintain the self-renewal process and differentiation into spermatozoa throughout the male reproductive life and transmit genetic information to the next generation. SSCs originate from gonocytes in the postnatal testis, which originate from long-lived primordial germ cells during embryonic development. The treatment of infertility in males has a poor prognosis. However, SSCs are viewed as a promising alternative for the regeneration of the impaired or damaged spermatogenesis. SSC transplantation is a promising technique for male infertility treatment and restoration of spermatogenesis in the case of degenerative diseases such as cancer, radiotherapy, and chemotherapy. The process involves isolation of SSCs and cryopreservation from a testicular biopsy before starting cancer treatment, followed by intra-testicular stem cell transplantation. In general, treatment for male infertility, even with SSC transplantation, still has several obstacles. The efficiency of cryopreservation, exclusion of malignant cells contamination in cancer patients, and socio-cultural attitudes remain major challenges to the wider application of SSCs as alternatives. Furthermore, there are limitations in experience and knowledge regarding cryopreservation of SSCs. However, the level of infrastructure or availability of regulatory approval to process and preserve testicular tissue makes them tangible and accurate therapy options for male infertility caused by non-obstructive azoospermia, though in their infancy, at least to date.

Keywords: infertility; male; spermatogenesis; spermatogonial stem cells

\section{Male Infertility}

Male infertility in humans is defined as the inability to fertilize their female counterpart through unprotected copulation for a period of 12 months and more [1]; the World 
Health Organization (WHO) has defined infertility as incapability to conceive a child after unprotected, regular sexual intercourse for at least 12 months [2]. At least 30 million men worldwide suffer from infertility, with the highest prevalence found in Africa and Eastern Europe. However, because of the varying opinions with different credibility and older articles, it is quite difficult to provide accurate statistics [3]. Infertility is considered one of the main health problems affecting couples in the reproductive age, affecting about $8-12 \%$ of couples worldwide [4], and it was estimated that the prevalence of age-standardized infertility increased by $0.370 \%$ in women and by $0.291 \%$ in men every year between 1990 and 2017 [5], according to a global burden of disease survey. Infertility is associated with physiological and economic burdens as well as social distress among patients, their families, and healthcare systems; therefore, early detection of the problem and proper management is very important [6-8].

Causes of infertility could be attributed to the man only in about $20-30 \%$ of couples, $[9,10]$. Several studies have observed a decline in sperm count over the years, and a meta-analysis conducted in 1992 observed that sperm count has decreased by $50 \%$ over 60 years, which was confirmed by another large systematic review that reported that between 1973 and 2011, sperm count has declined by 50-60\% [11-14]. Male infertility is attributed to the diminished quantity or quality of the ejaculate, and when sperm are not found in the ejaculate, the case called azoospermia. Azoospermia can be caused by obstructive reasons such as congenital bilateral absence of vas deferens, congenital obstruction of the duct system, incomplete patency of the vas deferens, or slow maturation of spermatozoa in the epididymis $[15,16]$. Non-obstructive azoospermia can be caused by congenital causes such as Kallmann syndrome, Klinefelter syndrome, genetic endocrinopathy, cryptorchidism, microdeletions of the $\mathrm{Y}$ chromosome, anorchia, and idiopathic mild androgen insensitivity syndrome [17]. Acquired causes of non-obstructive azoospermia include varicocele, which is the most common cause of infertility in men [18], germ cell tumors, acquired hypogonadotropic hypogonadism ( $\mathrm{HGH}$ ), exogenous factors such as exposure to chemotherapy or radiation or cytotoxic drugs, recurrent urogenital infections, and other systemic diseases and surgeries that can affect spermatogenesis or male endocrine functions [19]. Idiopathic factors include unknown causes of male infertility and account for approximately $30-50 \%$ of infertile male cases [20], including environmental factors such as exposure to toxic chemicals [21], lifestyle factors such as obesity [22], smoking [23], and alcohol consumption [24], and psychological factors such as emotional stress, anxiety, and depression $[25,26]$. In this review, we shed the light on the potential of treating infertility caused by non-obstructive azoospermia through cellular therapy using spermatogonial stem cell transplantation.

\subsection{Azoospermia}

Azoospermia is defined as the absence of spermatozoa or sperm in the semen; it is considered the cause of infertility in approximately $10 \%$ to $15 \%$ of fertility in men [27]. This could be due to pretesticular, testicular, or post-testicular causes. Pretesticular causes of azoospermia include hormonal problems of the hypothalamic-pituitary-gonadal axis [28]. Testicular causes include abnormalities in the spermatogenesis process occurring inside the testis, and post-testicular causes include obstructions of ducts in the male reproductive system [29]. Pretesticular and post-testicular causes are usually treated, and fertility can be restored, while testicular causes are usually not reversible, with low success rates of several interventions. Pretesticular causes and testicular causes are considered to be nonobstructive causes of azoospermia, while post-testicular causes are considered to be the obstructive causes of azoospermia.

\subsubsection{Pretesticular Causes}

Pretesticular causes are usually due to pathological endocrinal problems in origin, and they are also called secondary testicular failure, affecting up to 3\% of infertile males [30]. $\mathrm{HGH}$ is a rare cause of infertility in men and is characterized by a decline in testosterone, 
luteinizing hormone ( $\mathrm{LH})$, and follicle-stimulating hormone (FSH), which can be congenital or acquired, and it is considered as one of the treatable causes of male infertility. Causes of HGH include pituitary gland tumors, pituitary gland traumas, Kallmann syndrome, and anabolic steroid use [31].

Kallmann syndrome, the most common cause of congenital HGH, is caused by abnormalities in the midline cranial structures, and is characterized by decreased secretion of gonadotropin-releasing hormone $(\mathrm{GnRH})$ from the hypothalamus resulting from failed migration of GnRH-releasing neurons during development to the olfactory lobe [32]. The disease is X-linked, and it has been reported that it is caused by mutations in the KAL gene represented on Xp22.3 position [33]. Androgen resistance is another congenital cause of $\mathrm{HGH}$, which occurs due to several mutations of the androgen receptor gene on the $X$ chromosome [34,35], affecting males and females leading to infertility; although androgen resistance is complete in females, it is partial in males and both results in infertility. Testosterone levels can increase, decrease, or remain normal according to the severity of genetic defects, and impaired androgen receptor is the primary cause of decreased or absent sperm in $40 \%$ of infertile men [36]. Acquired causes of HGH include tumors of the pituitary gland, panhypopituitarism, trauma of the pituitary gland, and using anabolic steroids [37]. Exogenous testosterone inhibits the secretion of gonadotropins by a negative feedback loop, leading to the inhibition of the hypothalamic-pituitary-gonadal axis [38]. Using anabolic steroids excessively increases androgen levels, resulting in decreased levels of intratesticular testosterone levels and decreased FSH levels, resulting in impaired spermatogenesis, which leads to azoospermia and infertility in men [39]. Hyperprolactinemia causes HGH by inhibition of GnRH secretion in the hypothalamus caused by excess prolactin, which also causes a decline in FSH and LH hormone levels [40,41]. Hyperprolactinemia could be a consequence of using certain medications such as antihypertensive drugs, tricyclic antidepressants [42], or due to certain tumors such as pituitary gland tumors, including prolactin-secreting microadenoma, and prolactin-secreting macroadenoma, which leads to the destruction of the anterior pituitary gland and increased prolactin secretion, which could also be idiopathic [43].

\subsubsection{Testicular Causes}

They are identified as a primary testicular failure caused by internal abnormalities affecting the process of spermatogenesis inside the testis, which could result from developmental errors, genetic mutations, and the genotoxic effect of certain medications. Varicocele is a medical condition resulting from dilatation of veins draining the testis and belonging to the pampiniform plexus, which affects approximately $25 \%$ of males with decreased sperm count and about $15 \%$ of normal males [7]. It is hypothesized that the mechanism by which varicocele affects the testis is to increase the temperature of the testis and production of reactive oxygen species resulting from the stasis of venous blood in the pampiniform plexus [44].

Cryptorchidism, also known as undescended testes, is one of the most common causes of azoospermia in men; it affects approximately $25 \%$ of patients with unilateral cryptorchidism, and $80 \%$ of patients with bilateral cryptorchidism [45]. Early treatment is important to decrease infertility risk, and success rates of treatment depend on the initial position of the testis [46].

Testicular torsion is defined as testicular spinning inside the scrotum, twisting blood vessels supplying it, leading to decreased blood supply and resulting in pain and swelling. Testicular torsion is considered a pediatric emergency that sometimes requires surgical intervention to avoid loss of testicles that would lead to decreased spermatogenesis and infertility $[47,48]$. It affects approximately 45 of every 1000 males under 25 years of age per year [49].

Orchitis is the inflammation of the testis, which is characterized by an accumulation of exudate inside and outside seminiferous tubules leading to its damage, which could be due to systemic or local inflammation, autoimmune and idiopathic origin, or infection by 
certain types of bacteria such as Chlamydia trachomatis, or mumps virus [50]. Orchitis is considered the most common manifestation of mumps infection in men; it can affect the testis unilaterally in $67 \%$ cases, and it could be bilateral in $33 \%$ of affected men, in $36 \%$ of them, resulting in testicular atrophy, which would lead to infertility in approximately $13 \%$ of patients $[50,51]$.

Several genetic abnormalities can cause infertility in men, including Klinefelter syndrome, 47(XYY) syndrome, XX male syndrome, and Y-chromosome microdeletions [52].

Importantly, cytotoxic drugs used in tumor therapy can lead to non-obstructive azoospermia. Although chemotherapy or radiotherapy have shown great advances in recent years with increased five-year cancer survival rates among children and adults, it could result in infertility as a long-term side effect, and $24 \%$ of treated cancer patients could suffer from impaired spermatogenesis and infertility in the long term [53].

Previous data showed that the testis is radiosensitive [54], and the degree of gonadal damage depends on the radiation delivery method and dosage. Impaired spermatogenesis and loss of germ cells can result from direct treatment of the testis or adjacent tissue by radiation [55]. It was observed that treatment of cancer with fractionated radiation for 3 to 4 weeks would result in delayed recovery of gonadal damage and lead to infertility [56]. High doses of radiation could also result in permeant azoospermia because it can kill all spermatogonial stem cells (SSC) $[57,58]$, while low doses were associated with lower rates of gonadal damage, and spermatogenesis recovery $[59,60]$.

Chemotherapeutic agents, especially alkylating medications, could also lead to a decrease in sperm count and infertility. Chemotherapy could result in 10- to 100-fold reduced sperm count, damage of Leydig cells, and azoospermia [61,62]; chemotherapy without or in addition to radiation is responsible for infertility in $60 \%$ of men treated at sites below their diaphragm [63]. The permanence and recovery rate of infertility associated with chemotherapy depends on the duration of treatment, addictive drugs, and doses of medications used. To date, it is difficult to accurately predict the risk factors of azoospermia, whether it is temporary or permanent, and recovery rates of spermatogenesis [64].

\subsubsection{Post-Testicular Causes}

Post-testicular causes are considered obstructive azoospermia, which usually results from obstructions of ducts carrying sperm or impaired ejaculation. The absence of vasa deferentia is a congenital disease characterized by bilateral absent vas deferens, accounting for $6 \%$ of obstructive azoospermia patients and about $1 \%$ of infertile patients [65]. The absence of vasa deferens can result from abnormal cystic fibrosis transmembrane regulator gene (CFTR) [66], and it has been reported that CFTR mutations are present in $80 \%$ of men with bilateral absence of vas deferens, and $43 \%$ of those with unilateral vas deferens. The absence of vas deferens can also result from the abnormal differentiation of the mesonephric duct $[67,68]$. Obstruction of vas deferens is another cause of obstructive azoospermia. The main cause of obstructed vas deferens is a vasectomy procedure that is usually carried out for elective sterilization [69]. Another cause of obstruction is an accidental injury during inguinal hernia repair [70], or it could result from an inflammatory reaction against polypropylene mesh used during inguinal hernia repair [71].

Ejaculatory duct obstruction can also lead to obstructive azoospermia and infertility in about 1 to $5 \%$ of cases [72], which could be congenital due to Mullerian or Wolffian cysts, or acquired due to trauma, seminal vesicle calculi, or calcification of the prostate, which could affect one or both ejaculatory ducts $[73,74]$. Ejaculatory dysfunction includes a group of disorders with impaired ejaculation, such as premature ejaculation, retrograde ejaculation, anejaculation, and delayed ejaculation. The prevalence of ejaculatory dysfunction in infertile men is below $2 \%$, and it is not considered a common cause of infertility in men $[75,76]$. Of note, infertility caused by obstructive azoopermia can be treated through some surgical approaches and using assisted reproductive techniques such as in vitro fertilization (IVF), intracytoplasmic sperm injection (ICSI), or even testicular sperm aspiration (TESA) and testicular sperm extraction (TESE) [30,77]. 


\subsubsection{Other Causes of Male Infertility}

In addition to cytotoxic drugs, some drugs could affect men fertility, leading to reduced sperm count. Sirolimus, an immunosuppressive drug, can lead to decreased sperm count and motility as a result of seminiferous tubule dystrophy and decreased intratesticular testosterone levels. Antihypertensive drugs such as calcium channel blockers and betablockers affect erectile function and testosterone levels. Serotonin reuptake inhibitors, which are antidepressant and antipsychotic drugs, could lead to hyperprolactinemia, which results in azoospermia and infertility, while diuretics such as aldosterone can lead to infertility by inhibiting testosterone biosynthesis, inhibiting androgen binding to target cells, and impairing sperm motility [78].

\section{Spermatogonial Stem Cell as New Option to Treat Impaired Spermatogenesis}

Spermatogenesis starts after puberty, in which spermatogonia undergo mitotic and meiotic divisions, resulting in haploid spermatids and spermatozoa (Figure 1). The final steps for spermatozoa maturation occur in the epididymis. Since spermatogenesis is considered a stem cell-based mechanism [79], one way to treat male infertility caused by impaired spermatogenesis is through stem cell transplantation (Figure 1). This is because stem cells are unspecialized cells that can self-renew, regenerate, and differentiate into other cell types [80]. SSCs can restore spermatogenesis when spermatogonial cells get damaged and/or depleted $[79,81]$. Therefore, stem cell transplantation represents a promising technique for reviving spermatogenesis in cancer patients and other patients who suffer from impaired spermatogenesis $[82,83]$. Patients with cancer who undergo radiation or chemotherapy suffer from male infertility as a consequence of the treatment side effects. Therefore, fertility maintenance has become a major concern in the care of prepubertal boys receiving cancer treatment. Accordingly, testicular biopsy is performed, and autologous SSCs are isolated and cryopreserved before cancer treatment, followed by stem cell transplantation intra-testicularly $[82,84]$. On the other hand, other stem cell types have also been used for azoospermia treatment. For instance, mesenchymal stem cells (MSCs), embryonic stem cells (ESCs), very small embryonic-like stem cells (VSELs), and induced pluripotent stem cells (iPSCs) are obtained from normal somatic cells $[3,83]$.

SSCs are characterized by their capacity to maintain the self-renewal process and possess the pluripotency [85-87] where they can differentiate as any stem cell type; the basis of spermatogenesis and male fertility are SSCs, which are rare and constitute only $0.03 \%$ of all germ cells in rodent testicles, while SSCs are greatly outnumbered by the differentiating spermatogonia, spermatocytes, spermatids, and sperm produced by them [88]. This equilibrium retains the population of stem cells and satisfies the proliferative requirement of the testis to generate millions of sperm daily [89]. The development of this unique cell form provides novel biotechnological solutions to existing human issues as a result of ongoing and comprehensive SSC biomedical research.

SSCs originate from gonocytes in the postnatal testis that originate from long-lived primordial germ cells (PGCs) during early embryonic development. PGCs are a transient cell population that are first detected in the epiblast stage embryo as a small cluster of alkaline phosphatase-positive cells at around 7-7.25-days post coitum (dpc) in rodents, while in humans, they were noticed in the yolk sac wall, close to the allantois around $24 \mathrm{dpc}$ in humans [90] and depends on the extraembryonic ectodermal expression of BMP4 and BMP8b $[86,87]$. The PGCs are passively swept out of the embryo during the development of the allantois until they begin to migrate through the hindgut to enter the oblivious gonadal ridge in mice between 8.5 and $12.5 \mathrm{dpc}$, and between 29-33 dpc in humans [91]. During the migration pattern process, approximately 3000 PGCs colonize the genital ridges [92]. PGCs give rise to gonocytes that are enclosed in testicular cords constituted by Sertoli precursor cells and peritubular myoid cells in the male gonads at approximately $13.5 \mathrm{dpc}$. The general definition of gonocytes can indeed be subclassified into mitotic (M)-prespermatogonia, T1-prospermatogonia, and T2-prospermatogonia [93]. M-prespermatogonia is found in the middle of the testicular cords, farther from the basement membrane, and when they 
become T1-prospermatogonia and reach G0 mitotic arrest, they tend to proliferate until around $16.5 \mathrm{dpc}$ of rodent development [94]. Gonocytes begin proliferating and migrate to the seminiferous tubules of the basement membrane within the first week after birth (marking their transition to T2-prospermatogonia) [95]. The first round of spermatogenesis occurs in T2-prospermatogonia that colonize the basement membrane and the initial pool of SSCs that sustain spermatogenesis during post-pubertal life $[93,96]$.
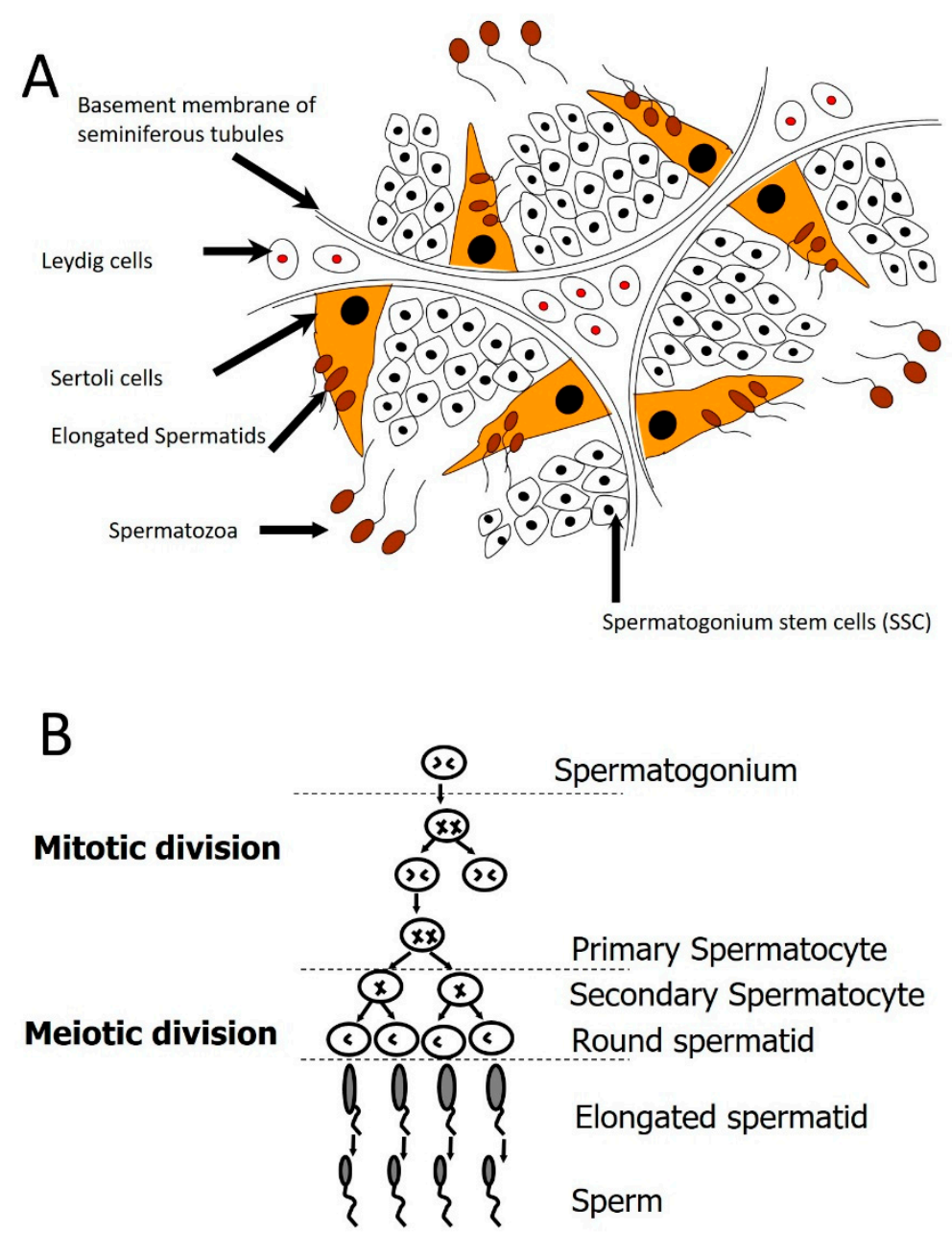

Figure 1. The process of spermatogenesis. (A) A cross-section in the testis, showing the process of spermatogenesis occurring in the seminiferous tubules with the aid of Sertoli cells. (B) After puberty, spermatogonial stem cells proceed into infinite mitotic and meiotic divisions resulting in millions of spermatozoa [97].

It is crucial to understand SSCs in the sense of the spermatogenic lineage they generate in an attempt to comprehend the regulation of SSCs. Spermatogonia, found on the basement membrane of seminiferous tubules, are diploid germ cells. Spermatogenic lineage development differs between rodents and humans [98]. In rodents, three types of spermatogonia were originally identified based on their nuclear morphology [99]. Type A spermatogonia are known to be the most primitive because the nucleus lacks heterochromatin, a general feature of undifferentiated cells. There is a reasonable quantity of heterochromatin in the nuclei of intermediate-type spermatogonia and a significant amount of heterochromatin in type B spermatogonia, suggesting a more differentiated state [100]. Studies have shown that undifferentiated type A spermatogonia can indeed be subcategorized into spermatogonia of A single (As), A paired (Apr), and Aligned (Aal), which vary only in their topographical configuration on the basement membrane of the seminiferous tubule $[101,102]$. It generates an Apr when an As spermatogonium divides, 
that either (i) perform cytokinesis to produce two new As spermatogonia or (ii) persists linked by an intercellular cytoplasmic bridge and generates a chain at the next division of four Aal spermatogonia. Additional cell divisions contribute to the development of 8 , 16, and occasionally 32 Aal spermatogonia chains; chains of 4-16 Aal are usually deemed dedicated to the mechanism of differentiation. Therefore, the pool of stem cells contains As and some Apr spermatogonia. Some may have argued that stem cells could expand to larger clones [103,104]. The smaller chains of As, Apr, and four Aal spermatogonia were uniformly distributed around the seminiferous epithelium. Larger Aal chains (8, 16, and 32) differentiate A1 spermatogonia between stages IV and VIII of the seminiferous epithelium, and at stage IX, these eventually lead to A2 spermatogonia. Therefore, unlike undifferentiated spermatogonia, differentiating spermatogonia A1, A2, A3, A4, intermediate, and $\mathrm{B}$ divide synchronously and occur at particular stages of the seminiferous epithelium. B spermatogonia generate primary spermatocytes that advance into meiosis, and two meiotic divisions contribute to the development of secondary spermatocytes and haploid spermatids, which induce morphological changes in 16 stages and gradually become sperm close to completion from the seminiferous epithelium $[105,106]$.

In humans, the A0/A1 model is an alternative to the As model of SSC self-renewal, which is very close to the model of Adark and Apale used in non-human primates to characterize stem cell potency [98]. Adark spermatogonia act as reserve stem cells, while Apale spermatogonia are the self-renewing stem cells. There is only one generation of type B spermatogonia before differentiation into spermatocytes, which makes human spermatogenesis less efficient than in rodents [107]. A0 spermatogonia were identified as single cells or pairs of cell types found in the seminiferous epithelium during all phases. In these cells, mitotic measurements were seldom found, and therefore they were assumed to not lead to stable spermatogenesis as reserve stem cells. These reserve stem cells are triggered only by harmful threats, such as radiation, and disable spermatogenesis. A1-A4 spermatogonia are part of the functional stem cell pool. They inevitably lead either to new A1 spermatogonia (described as self-renewal) or intermediate spermatogonia if A4 spermatogonia split (described as differentiation) [108-110].

SSCs locate within a standardized microenvironment called 'niche', which, by maintaining SSC self-renewal, quiescence, pluripotency, and differentiation, controls testicular homeostasis [111]. In the atmosphere of stem cells that govern cell fate, a stem cell niche is made up of cells, extracellular fluids, and local soluble factors. The basal region of the seminiferous tubules containing Sertoli cells and peritubular myoid cells is the structural basis for the SSC niche in mammalian testes [112]. Sertoli cells produce growth factors that stimulate self-renewal (Glial cell line-derived neurotrophic factor, and basic fibroblast growth factor) and differentiation (activin A, bone morphogenetic protein 4, and stem cell factor) of the SSCs, as well as other factors to maintain the microenvironment such as chemokine (C-X-C motif) ligand 12, vascular endothelial growth factor A, inhibin $\beta A$, NOTCH and WNT5A $[113,114]$. Sertoli and peritubular myoid cells simultaneously release the constituents of the basement membrane to which SSCs are linked through binding proteins [115]. Sertoli cells sustain SSCs and differentiate germ cells in addition to supporting spermatogenesis by supplying nutrients and modulating external signals [116]. Transplantation of normal Sertoli cells into the testes of infertile mutant patients with Sertoli cell deficiency and successful induction of spermatogenesis by recipient-derived spermatogonia have shown the significance of Sertoli cells in germ cell proliferation [117,118]. A protective blood-testis barrier (BTB) is a close junction between adjacent Sertoli cells, which divides the seminiferous epithelium into basal and adluminal compartments and plays a vital role in controlling germ cell proliferation [119]. BTB ensures preferential circulation of substances between the luminal fluid, bloodstream, and interstitial fluid, providing an immune-privileged environment in the adluminal compartment of the seminiferous tubules for haploid germ cells [119]. 


\subsection{Spermatogonial Stem Cell Transplantation for Regeneration}

Brinster and colleagues were the first to identify a technique for transplanting SSCs [120]. Fertility preservation in rodents after SSC transplantation indicates that this technique could have medical application in humans $[83,121]$. The critical points are the success of SSCs storage (good cryopreservation) and transplantation, and when transplanted, induction of spermatogenesis [122]. Testicular biopsy and cryopreservation are promising tools for people with cancer and undergoing cancer treatment. Scientists were able to propagate SSCs in humans in vitro. However, more research is required to overcome some challenges and improve outcomes [123]. Lim et al. proved that SSCs found in the testes of patients with non-obstructive azoospermia can be extracted, isolated, and propagated in vitro via a highly efficient culture system, resulting in the differentiation of germ cells with developmental potential [124].

\subsubsection{Testicular Biopsy/Tissue}

Under sterile conditions, a biopsy is obtained from the testis of children with cancer before undergoing treatment or from adult patients with azoospermia, regardless of the cause. An alternative method for biopsy is to obtain testicular tissue in humans. In contrast, in the case of animals such as rodents, whole testes are obtained and preserved in sterile Hanks' balanced salt solution (HBSS) [125]. To obtain a single-cell suspension from the young, the testicular tissue must be digested via enzymatic digestion by mixing it with trypsin-EDTA solution and DNase I solution. The cell suspension is washed with HBSS after passing through a 40-m pore cell strainer, and then centrifuged (cool centrifuge) to obtain a pellet. In the case of adult animals, the testes are mixed with collagenase solution and DNase I solution, mixed until the separation of the seminiferous tubules, added in HBSS in ice until complete sedimentation occurs, the supernatant discarded, the tubules washed with HBSS to remove the interstitial cells, and then complete the same steps performed in case of young cases until the pellets are obtained via cool centrifugation [126,127]. A similar technique has been used in fish, such as Brycon orbignyanus [128].

\subsubsection{SSCs Isolation}

Goodyear and Brinster established a complete protocol for SSCs in mice, including isolation, culturing, expansion, and eventually transplantation [126,127], while Jon Oatley designed a protocol for cryopreservation and thawing [129]. The process of spermatogonial stem cell isolation starts from the digestion (type I collagenase and trypsin) of the obtained testicular tissue or the biopsy to obtain a single cell suspension via mechanical disruptions or enzymes such as trypsin, as discussed above. This can be done via Percoll isolation, which is a highly efficient tool used for separation depending on density gradient centrifugation $[125,130]$. Therefore, it is used to obtain SSCs via a few simple steps. After obtaining the pellet, HBBS is added for pellet resuspension, and diluted until it reaches $20 \times 10^{6}$ per volume of $5 \mathrm{~mL}$. The cell suspension layer is obtained above Percoll solution. The cell pellets are mixed with PBS-S, and the cell concentration is calculated. The cell content is diluted to $5 \times 10^{6}$ cells $/ \mathrm{mL}$. Then the process of cell sorting is performed via magnetic-activated Cell Sorting (MACS) to select Thymus cell antigen 1 (Thy1+) or octamerbinding transcription factor 4 (Oct4+) or the promyelocytic leukaemia zinc finger (PLZF+) cells which are specific for SSCs $[125,130,131]$. Thy1 antibody-conjugated microbeads are added to the cell suspension (cell pellet with PBS) containing the SSCs with specific dilutions, and then incubated at a specific temperature for a certain time. After sterilization and preparation of the MACS column, the cell suspension containing the Thy $1+$ antibody microbeads are allowed to pass, and the solution containing the Thy1+ cells in serum-free medium is eluted, and the cell concentration calculated. Now we have Thy1+ cells, and by this, the process of SSC isolation is completed [115,117]. Moreover, a discontinuous density gradient is also used in the process of SSC isolation in fish, such as Brycon orbignyanus [128]. 


\subsubsection{SSCs Culturing and Expansion}

After isolation of SSCs or after preservation, culture and expansion are required to propagate the cells. Preparation of a primary culture of SSCs is done via preparation of mitomycin-treated STO feeders [132], washing them with HBBS, and adding the SSCs either freshly isolated or cryopreserved. Then, $0.5-1 \times 10^{5}$ Thy $1+$ cells are added in each plate in 12-well tissue culture plates, and SFM, GDNF, and bFGF are added. The tissue culture plate is placed in a $\mathrm{CO}_{2}$ incubator at $37^{\circ} \mathrm{C}$, and the medium is changed every 2-3 days. Then, the process of expansion is performed for the obtained undifferentiated SSC $_{S}$ by washing with PBS and then using trypsin-EDTA for dissociation; the cells are incubated in a $\mathrm{CO}_{2}$ incubator, the effect of trypsin is stopped by adding FBS, and cell suspension is obtained by mixing and pipetting, followed by centrifugation to obtain the pellet, SFM, centrifugation, and resuspended again in SFM, GDNF and bFGF. Finally, the suspension is added to the STO feeder layer $[127,129]$. In humans, the xeno-free and feeder-free culture systems are required for clinical applications [133,134]. For instance, matrigel-based and hydrogel-based culture systems were successfully reported for mice SCC culture $[135,136]$. While in human, three-dimensional culture system using agarose gel was used to improve the differentiation of SCC to spermatocytes and spermatids [131]. Hydrogel-coated or gelatin-coated dishes together with growth factor (GDNG, bFGF, GFRA1-Fc fusion protein, NUDT6, TGFB, EGF, and LIF) were used for propagation of human GPR125+ spermatogonia [137-140].

\subsubsection{SSCs Transplantation}

SSC transplantation requires the preparation of recipients. The previous protocols were about the preparation of SSCs from donors. Whether they are autologous or allogeneic or xenogeneic depends on the study purpose and the aim of protocol execution. The initial trials showed the survival of human SCC in mice testis after six months of injection. However, there was no human sperm resulted from this trial [141]. Furthermore, SCC was successfully subsided to the seminiferous tubules after injection into azoopsermic mice [142]. Successful completion of SSC transplantation and retrieval of sperm was reported after 12 months of SCC injection in irradiated dog testis [143]. Recently in the monkey, SSC transplantation partially restored the functional sperm production when testis was irradiated before and after puberty [144]. An important step towards application in humans. In mice, preparation of the recipients is performed via injection of busulfan intraperitoneally to remove the endogenous germ cells in the recipient mice, the injection occurs in bodyweight and species-dependent doses. Animals are left for six weeks to guarantee complete depletion of spermatogenesis before the process of SSC transplantation, to be able to assess and judge that the produced spermatogenesis comes from the transplanted SSCs [129].

For SSC transplantation, there are two cases; the first case is wherein the whole testis or the testicular tissue is freshly obtained, and therefore the preparation protocol is needed, while the second case is wherein the cells are already isolated and cultured. In the case of tissues of the whole testis, the tunica albuginea should be removed, the testes added in HBBS, collagenase for separation of the seminiferous tubules, HBBS, trypsin-EDTA added for digestion and cell dispersion, and centrifugation, washing, and resuspension in SFM. In the second case of the culture, a cell suspension is directly performed in SFM. Then, both cases complete the same pathway with the addition of trypan blue for easy gross monitoring during injection, then directly microinjecting the cells in the seminiferous tubule lumen, followed by monitoring and keeping the transplanted recipient males for an additional eight weeks to allow for robust donor-derived spermatogenesis [129]. Figure 2 illustrates the sequences for SCCs transplantation. In contrast, in fish, a simple protocol was designed to perform SSC transplantation from one species to another, that is, from Brycon orbignyanus (donor) to Astyanax altiparanae (recipient). This was done via enzymatic digestion of the testes, then isolation by density gradient, adding busulfan for germ cell suppression, labeling the SSCs with PKH26, and injecting the recipient fish with SSCs via 
the urogenital papilla. Twenty-one days after transplantation, sperm were detected in the lumen [128]. The various types of culture media used and the level of achievement in testicular tissue culture in different species are summarized in Table 1.

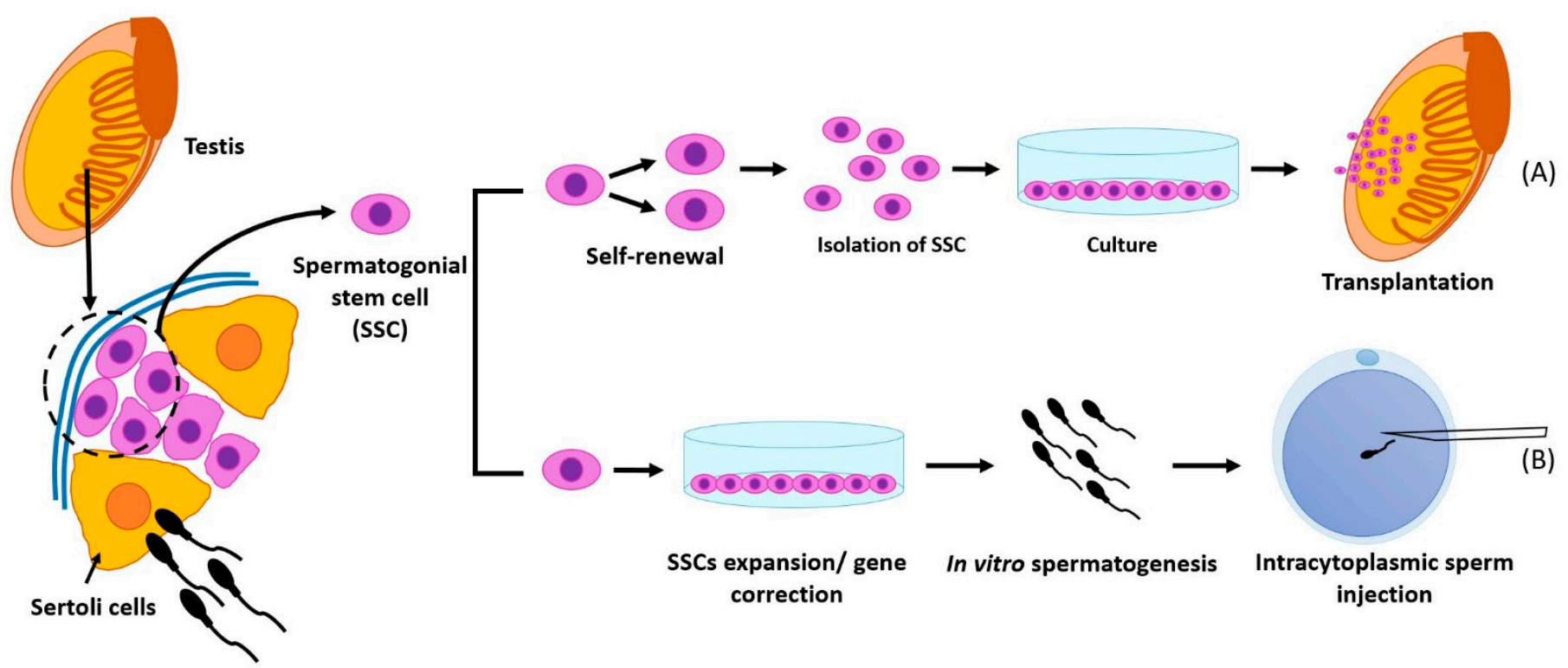

Figure 2. Schematic illustration of spermatogonial stem cells (SSCs) as treatment option for male infertility, (A) Transplantation of SSCs into infertile testis after in vitro propagation, (B) Application of spermatozoa in intracytoplasmic sperm injection after in vitro spermatogenesis of SSCs.

Table 1. Milestone and trends of using spermatogonial stem cells to treat impaired spermatogenesis and non-obstructive azoospermia in different species.

\begin{tabular}{|c|c|c|c|c|}
\hline Species & $\begin{array}{c}\text { Level of In Vitro Culture } \\
\text { Achieved }\end{array}$ & $\begin{array}{c}\text { Time of In Vitro Culture } \\
\text { (Year Achieved) }\end{array}$ & Culture Media Used & Reference \\
\hline \multirow[t]{2}{*}{ Human } & Testicular tissue maintained & Several weeks (1970) & $\begin{array}{c}\text { Eagle's minimum } \\
\text { essential media (MEM) }\end{array}$ & [92] \\
\hline & $\begin{array}{c}\text { Propagation of SSCs but in } \\
\text { undifferentiated }\end{array}$ & $\begin{array}{l}\text { Two months propagation } \\
\qquad(2015)\end{array}$ & $\begin{array}{c}\text { StemPro-34 SFM } \\
\text { (serum free medium) }\end{array}$ & [137] \\
\hline \multirow[t]{2}{*}{ Monkey } & Maintained SSCs & Only short time (2012) & $\begin{array}{l}\text { Germline culture } \\
\text { medium }\end{array}$ & [145] \\
\hline & Maintained SSCs & Effective for longer time (2017) & Stem-Pro medium & [146] \\
\hline \multirow[t]{5}{*}{ Mouse } & $\begin{array}{l}\text { Organ (testicular) fragment } \\
\text { maintained }\end{array}$ & 6 days (1959) & Eagle's MEM & [147] \\
\hline & $\begin{array}{c}\text { Organ (testicular) fragment } \\
\text { maintained }\end{array}$ & 4 weeks (1964) & Eagle's MEM & [148] \\
\hline & $\begin{array}{l}\text { Organ maintained and } \\
\text { differentiation of } \\
\text { spermatogonia to } \\
\text { spermatocytes }\end{array}$ & 2-3 weeks of culture (1964) & Eagle's MEM & [149] \\
\hline & $\begin{array}{l}\text { Differentiation of type A } \\
\text { spermatogonia into meiotic } \\
\text { pachytene spermatocytes }\end{array}$ & After 3 weeks (1993) & $\begin{array}{l}\text { FSH supplemented } \\
\text { Eagle's MEM }\end{array}$ & [150] \\
\hline & $\begin{array}{l}\text { Round spermatids observed } \\
\text { (able to fertilize oocyte) }\end{array}$ & After 2 weeks of culture (2003) & $\begin{array}{l}\text { Gas-liquid interface } \\
\text { culture system }\end{array}$ & [151] \\
\hline
\end{tabular}


Table 1. Cont.

\begin{tabular}{|c|c|c|c|c|}
\hline Species & $\begin{array}{c}\text { Level of In Vitro Culture } \\
\text { Achieved }\end{array}$ & $\begin{array}{l}\text { Time of In Vitro Culture } \\
\text { (Year Achieved) }\end{array}$ & Culture Media Used & Reference \\
\hline & $\begin{array}{l}\text { Obtained spermatid and } \\
\text { sperm (Produced } \\
\text { reproductively competent } \\
\text { offspring by } \\
\text { microinsemination) }\end{array}$ & $\begin{array}{c}\text { After } 2 \text { months (2011) [the first } \\
\text { successful IVS] }\end{array}$ & $\begin{array}{l}\text { Gas-liquid interface } \\
\text { culture system (serum } \\
\text { free) }\end{array}$ & [152] \\
\hline & $\begin{array}{l}\text { Haploid male germ cells } \\
\text { obtained from infertile } \\
\text { mutant mouse (Offspring } \\
\text { produced) }\end{array}$ & Monitored growth (2012) & $\begin{array}{l}\text { Agarose gel in } \alpha \text {-MEM } \\
\text { supplemented with KO } \\
\text { serum replacement } \\
(\mathrm{KSR}) \text { or AlbuMAX }\end{array}$ & [153] \\
\hline & $\begin{array}{l}\text { IVS also achieved from } \\
\text { cryopreserved testis tissue } \\
\text { (Offspring produced) }\end{array}$ & Monitored growth (2014) & $\begin{array}{l}\text { Agarose gel in } \alpha \text {-MEM } \\
\text { supplemented with } \\
\text { KSR or AlbuMAX }\end{array}$ & [154] \\
\hline Minipig & $\begin{array}{c}\text { SSCs differentiate and } \\
\text { develop to a post-meiotic } \\
\text { stage }\end{array}$ & Ten days culture (2018) & $\begin{array}{l}\text { MEM- } \alpha \text { supplemented } \\
\text { with KO serum } \\
\text { replacement }\end{array}$ & [155] \\
\hline
\end{tabular}

\subsection{In Vitro Spermatogenesis Using Spermatogonial Stem Cells}

Testicular spermatogonial tissues from a prostate cancer patient were cultured for 27 days and developed into spermatids [92]. On the other hand, the culturing of germline spermatids cells, from testicular tissue biopsies in obstructive azoospermia patients, provides new hope that immature spermatids could mature into mature sperm via in vitro spermatogenesis (IVS) [156] (Figure 2). Similar findings have also been reported by Cremades et al. (1999), where spermatids from non-obstructive azoospermia have been successfully cultured, resulting in IVS, and round spermatids have developed into elongated spermatids [93]. Recently, the Vero cell culture system has been complemented to enhance IVS by supplementing culture media with $50 \%$ boar rete testicular fluid or in human synthetic oviduct fluid and $10 \%$ human serum, improving IVS rate to $10 \%$, and yielding haploid sperm [94]. And, recently, through the development of an organotypic culture system, IVS achieved from pre-pubertal human testicular tissue (immature spermatids) has been reported from 16 days of culture, resulting in round spermatids [95].

The milestone progress in in vitro spermatogenesis using SSCs from cryopreserved testicular organs was in 2011 using serum-free gas-liquid interface culture in mice [153]. Efforts were made in different species, humans, and Bama minipigs, and various levels of success were attained (Table 1). For the IVS to achieve the required fertility, in addition to spermatid elongation, additional evidence of fertility indicators must be obtained in terms of genetic and epigenetic fertility in haploid cells. Perhaps, it is to be demonstrated and clinically proven [10]. On the other hand, the scarcity of spermatid tissue to perform IVS for the long term and the limitation of available data will not allow conclusive remarks regarding its success. Some trials have been conducted to protect spermatids against membrane damage and to augment the motility of differentiated spermatozoa. Dumont et al. used retinol (vitamin A) to culture mouse prepubertal testicular tissue and found an improvement in the differentiation of SSCs into motile spermatozoa after culturing for 30 days [157]. Interestingly, IVS was improved in rats by supplementing the culture medium with hormones (testosterone, thyroxin, $\mathrm{FSH}$, and $\mathrm{LH}$ ), antioxidants (glutathione and ascorbic acid), and lysophospholipids (L-a-Lysophosphatidylcholine and lysophosphatidylserine) under hypoxic culture conditions for 70 days [158]. Recently, retinoic acid in combination with stem cell factor (SCF) improved IVS and differentiation of SSCs in rats by upregulating PRTM1, STRA8, c-KIT, PIWIL2, and OCT4 gene expression [159]. Furthermore, vitamin $\mathrm{E}$ was effective in IVS as a reactive oxygen species (ROS) scavenger and an effective molecule to improve the yield of in vitro spermatogenesis from frozen thawed prepubertal mouse testicular tissue [160]. 


\section{Other Stem Cell Types (iPSCs, ESCs, VSELs, and MSCs)}

SSCs are used in this process; however, other stem cell types can also be used, particularly in patients who do not have SSCs. Therefore, other stem cells represent hope for these people to allow them to have offspring in the future. ESCs are extracted from the inner blastocyst cell mass and are considered to be pluripotent cells that can differentiate into different cell lineages. They can also provide germ cell lines in vitro. However, there is an ethical controversy regarding the use of embryonic stem cells in humans. Moreover, during differentiation, ESCs lose their plasticity [3]. ESCs differentiate into male germ-like cells in vitro, but the disadvantage is that they are not genetically related to patients [96].

On the other hand, VSELs present in humans and mice are pluripotent as they can selfrenew and regenerate. Since VSELs are not affected by chemotherapy, they can contribute to germ cell development in men who have received chemotherapy as an infant $[161,162]$.

On the other hand, iPSCs, which have the ability to be reprogrammed can be used in the replacement of ESCs, thus preventing ethical controversy. The advantages of iPSCs are an easy sampling technique, that is, somatic cells such as skin can be obtained and then reprogrammed to produce germ cells. Therefore, there is currently research underway on iPSCs to differentiate into SSCs in patients that do not have their own SSCs $[3,83,132]$. SSC-like cells (SSCLCs) have been generated from pluripotent stem cells and showed self-renewal over four months of culture [163].

Mesenchymal stem cells (MSCs), which are multipotent stem cells, have been used in various disciplines and diseases because of their easy isolation, culture, and immunomodulatory effects, and have a very high safety profile. MSCs have been used in male infertility, as after injection of MSCs into a busulfan-induced azoospermic rat, complete spermatogenesis was observed, and MSCs were able to restore fertility [164,165]. Interestingly, co-transplantation of SSCs and TGF 31 -treated MSCs resulted in improving the reproductive efficiency of SSC transplantation even after transplanting half the number of SSCs [166]. Because of the easy retrieval and extensive work with animals, there are some registered and recruiting clinical trials that use different kinds of stem cells (bone marrow-derived and adipose-derived MSCs) for treating non-obstructive azoospermia and impaired spermatogenesis in human subjects. However, none of these trials has posted a clinical efficiency yet. In Table 2, we summarize the up-to-date trials existing on the website clinicaltrials.gov (last accessed on 4 July 2021).

Table 2. Registered clinical trials that use stem cells for treating impaired spermatogenesis.

\begin{tabular}{|c|c|c|c|c|c|}
\hline Subjects/Cases & Intervention & Outcome & $\begin{array}{l}\text { Geographic } \\
\text { Location }\end{array}$ & Status & Trial Identifier \\
\hline $\begin{array}{l}\text { Azoospermic } \\
\text { Patients }\end{array}$ & $\begin{array}{l}\text { Bone Marrow Derived } \\
\text { Mesenchymal Stem Cells }\end{array}$ & $\begin{array}{l}\text { No results } \\
\text { posted }\end{array}$ & Cairo, Egypt & Recruiting & NCT02025270 \\
\hline $\begin{array}{l}\text { Non-obstructive } \\
\text { Azoospermia }\end{array}$ & $\begin{array}{l}\text { Bone marrow derived } \\
\text { CD34+, CD133+, and } \\
\text { mesenchymal stem cells }\end{array}$ & $\begin{array}{l}\text { No results } \\
\text { posted }\end{array}$ & Amman, Jordan & Recruiting & NCT02641769 \\
\hline $\begin{array}{l}\text { Klinefelter } \\
\text { Syndrome } \\
\text { Azoospermia }\end{array}$ & $\begin{array}{c}\text { Bone marrow } \\
\text { Mesenchymal stem cell } \\
\text { injection }\end{array}$ & $\begin{array}{l}\text { No results } \\
\text { posted }\end{array}$ & Cairo, Egypt & Recruiting & NCT02414295 \\
\hline $\begin{array}{l}\text { Non-obstructive } \\
\text { Azoospermia }\end{array}$ & $\begin{array}{l}\text { Bone Marrow Derived } \\
\text { Stem Cells }\end{array}$ & $\begin{array}{l}\text { No results } \\
\text { posted }\end{array}$ & Giza, Egypt & Recruiting & NCT02041910 \\
\hline $\begin{array}{l}\text { Non-obstructive } \\
\text { Azoospermia }\end{array}$ & $\begin{array}{l}\text { Bone Marrow Derived } \\
\text { Stem Cells }\end{array}$ & $\begin{array}{l}\text { No results } \\
\text { posted }\end{array}$ & Cairo, Egypt & Recruiting & NCT02008799 \\
\hline $\begin{array}{l}\text { Azoospermia and } \\
\text { oligozoospermia }\end{array}$ & $\begin{array}{l}\text { Adipose-Derived Adult } \\
\text { Stromal Vascular Cells }\end{array}$ & $\begin{array}{l}\text { No results } \\
\text { posted }\end{array}$ & $\begin{array}{l}\text { Samara, Russian } \\
\text { Federation }\end{array}$ & $\begin{array}{l}\text { Enrolling by } \\
\text { invitation }\end{array}$ & NCT03762967 \\
\hline
\end{tabular}




\section{Conclusive Remarks}

Treatment of male infertility caused by impaired spermatogenesis via SSC transplantation, though promising, has not attained its potential and proper implementation and still has several obstacles. There is a need for more validation of the entire process of SSC transplantation. The efficiency of cell and tissue cryopreservation must be sought with high precaution as this step is very critical and the following alternative to treat infertility depends on the efficiency and effectiveness of cryopreserved SSCs. This step is critical for preserving the future fertility of children affected with cancer before they undergo cancer treatment and for the survival of SSCs before their depletion and degeneration by chemotherapy and radiotherapy.

In addition, cryopreservation, which is a crucial and critical challenge, may be affected by the malignant contamination of the testes of children with cancer. There are major concerns about enhancing the protocol efficiency without any damage to the testicular niche [84]. The socio-cultural attitude of a community and its perspective also remains a major challenge to the wider application of the possible alternative of SSCs under question. This is mainly because adult patients who can preserve sperm obtained from ejaculated semen or TESE are not being considered for stem cell therapies. There is a lack of experience and knowledge regarding cryopreservation of testicular tissue in prepubertal patients, and few institutions have the experience, infrastructure, or regulatory approval to process and preserve testicular tissue [82].

Overall, tangible and accurate therapy options in children and adults for male infertility are still in their infancy, and artificial reproductive assisted therapy has to progress much to attain a satisfactory level of male infertility therapy, at least to date.

Author Contributions: Conceptualization, N.E.A., B.M.T., M.A., S.A., M.F., I.M.S., S.B. and J.C.; writing-original draft preparation, N.E.A., B.M.T., M.A., S.A., M.F., I.M.S., S.B. and J.C.; writingreview and editing, N.E.A., B.M.T., M.A., S.A., M.F., I.M.S., S.B. and J.C.; funding acquisition, J.C. All authors have read and agreed to the published version of the manuscript.

Funding: This work was supported by a National Research Foundation of Korea (NRF) grant funded by the Korean government (MSIT) (No. 2021R1A2C2009294).

Acknowledgments: The authors are grateful to National Research Foundation of Korea (NRF) for funding this work.

Conflicts of Interest: The authors declare no conflict of interest.

\section{References}

1. Hull, M.G.; Glazener, C.M.; Kelly, N.J.; Conway, D.I.; Foster, P.A.; Hinton, R.A.; Coulson, C.; Lambert, P.A.; Watt, E.M.; Desai, K.M. Population study of causes, treatment, and outcome of infertility. Br. Med. J. (Clin. Res. Ed.) 1985, 291, 1693-1697. [CrossRef]

2. Zegers-Hochschild, F.; Adamson, G.D.; Dyer, S.; Racowsky, C.; de Mouzon, J.; Sokol, R.; Rienzi, L.; Sunde, A.; Schmidt, L.; Cooke, I.D.; et al. The International Glossary on Infertility and Fertility Care, 2017. Fertil. Steril. 2017, 108, 393-406. [CrossRef] [PubMed]

3. Pourmoghadam, Z.; Aghebati-Maleki, L.; Motalebnezhad, M.; Yousefi, B.; Yousefi, M. Current approaches for the treatment of male infertility with stem cell therapy. J. Cell Physiol. 2018, 233, 6455-6469. [CrossRef] [PubMed]

4. Vander Borght, M.; Wyns, C. Fertility and infertility: Definition and epidemiology. Clin. Biochem 2018, 62, 2-10. [CrossRef]

5. Sun, H.; Gong, T.T.; Jiang, Y.T.; Zhang, S.; Zhao, Y.H.; Wu, Q.J. Global, regional, and national prevalence and disability-adjusted life-years for infertility in 195 countries and territories, 1990-2017: Results from a global burden of disease study, 2017. Aging 2019, 11, 10952-10991. [CrossRef]

6. Bak, C.W.; Seok, H.H.; Song, S.H.; Kim, E.S.; Her, Y.S.; Yoon, T.K. Hormonal imbalances and psychological scars left behind in infertile men. J. Androl. 2012, 33, 181-189. [CrossRef] [PubMed]

7. Slade, P.; O'Neill, C.; Simpson, A.J.; Lashen, H. The relationship between perceived stigma, disclosure patterns, support and distress in new attendees at an infertility clinic. Hum. Reprod. 2007, 22, 2309-2317. [CrossRef]

8. Wu, A.K.; Elliott, P.; Katz, P.P.; Smith, J.F. Time costs of fertility care: The hidden hardship of building a family. Fertil. Steril. 2013, 99, 2025-2030. [CrossRef] [PubMed]

9. Anderson, J.E.; Farr, S.L.; Jamieson, D.J.; Warner, L.; Macaluso, M. Infertility services reported by men in the United States: National survey data. Fertil. Steril. 2009, 91, 2466-2470. [CrossRef] 
10. Thonneau, P.; Marchand, S.; Tallec, A.; Ferial, M.L.; Ducot, B.; Lansac, J.; Lopes, P.; Tabaste, J.M.; Spira, A. Incidence and main causes of infertility in a resident population $(1,850,000)$ of three French regions (1988-1989). Hum. Reprod. 1991, 6, 811-816. [CrossRef]

11. Carlsen, E.; Giwercman, A.; Keiding, N.; Skakkebaek, N.E. Evidence for decreasing quality of semen during past 50 years. BMJ 1992, 305, 609-613. [CrossRef] [PubMed]

12. Swan, S.H.; Elkin, E.P.; Fenster, L. The question of declining sperm density revisited: An analysis of 101 studies published 1934-1996. Environ. Health Perspect. 2000, 108, 961-966. [CrossRef]

13. Mishra, P.; Negi, M.P.S.; Srivastava, M.; Singh, K.; Rajender, S. Decline in seminal quality in Indian men over the last 37 years. Reprod. Biol. Endocrinol. 2018, 16, 103. [CrossRef]

14. Levine, H.; Jørgensen, N.; Martino-Andrade, A.; Mendiola, J.; Weksler-Derri, D.; Mindlis, I.; Pinotti, R.; Swan, S.H. Temporal trends in sperm count: A systematic review and meta-regression analysis. Hum. Reprod Update 2017, 23, 646-659. [CrossRef] [PubMed]

15. Krausz, C. Male infertility: Pathogenesis and clinical diagnosis. Best Pract. Res. Clin. Endocrinol. Metab. 2011, 25, 271-285. [CrossRef] [PubMed]

16. Zhankina, R.; Baghban, N.; Askarov, M.; Saipiyeva, D.; Ibragimov, A.; Kadirova, B.; Khoradmehr, A.; Nabipour, I.; Shirazi, R.; Zhanbyrbekuly, U.; et al. Mesenchymal stromal/stem cells and their exosomes for restoration of spermatogenesis in nonobstructive azoospermia: A systemic review. Stem Cell Res. Ther. 2021, 12. [CrossRef] [PubMed]

17. Salonia, A.; Rastrelli, G.; Hackett, G.; Seminara, S.B.; Huhtaniemi, I.T.; Rey, R.A.; Hellstrom, W.J.G.; Palmert, M.R.; Corona, G.; Dohle, G.R.; et al. Paediatric and adult-onset male hypogonadism. Nat. Rev. Dis. Primers 2019, 5, 38. [CrossRef]

18. Damsgaard, J.; Joensen, U.N.; Carlsen, E.; Erenpreiss, J.; Blomberg Jensen, M.; Matulevicius, V.; Zilaitiene, B.; Olesen, I.A.; Perheentupa, A.; Punab, M.; et al. Varicocele Is Associated with Impaired Semen Quality and Reproductive Hormone Levels: A Study of 7035 Healthy Young Men from Six European Countries. Eur. Urol. 2016, 70, 1019-1029. [CrossRef]

19. Finelli, R.; Leisegang, K.; Finocchi, F.; De Masi, S.; Agarwal, A.; Damiani, G. The impact of autoimmune systemic inflammation and associated medications on male reproductive health in patients with chronic rheumatological, dermatological, and gastroenterological diseases: A systematic review. Am. J. Reprod. Immunol. 2021, 85, e13389. [CrossRef]

20. Chehab, M.; Madala, A.; Trussell, J.C. On-label and off-label drugs used in the treatment of male infertility. Fertil. Steril. 2015, 103, 595-604. [CrossRef]

21. Ma, Y.; He, X.; Qi, K.; Wang, T.; Qi, Y.; Cui, L.; Wang, F.; Song, M. Effects of environmental contaminants on fertility and reproductive health. J. Environ. Sci. 2019, 77, 210-217. [CrossRef]

22. Eisenberg, M.L.; Kim, S.; Chen, Z.; Sundaram, R.; Schisterman, E.F.; Louis, G.M. The relationship between male BMI and waist circumference on semen quality: Data from the LIFE study. Hum. Reprod. 2015, 30, 493-494. [CrossRef]

23. Taha, E.A.; Ez-Aldin, A.M.; Sayed, S.K.; Ghandour, N.M.; Mostafa, T. Effect of smoking on sperm vitality, DNA integrity, seminal oxidative stress, zinc in fertile men. Urology 2012, 80, 822-825. [CrossRef]

24. Ricci, E.; Al Beitawi, S.; Cipriani, S.; Candiani, M.; Chiaffarino, F.; Viganò, P.; Noli, S.; Parazzini, F. Semen quality and alcohol intake: A systematic review and meta-analysis. Reprod. Biomed. Online 2017, 34, 38-47. [CrossRef]

25. Gaskins, A.J.; Afeiche, M.C.; Hauser, R.; Williams, P.L.; Gillman, M.W.; Tanrikut, C.; Petrozza, J.C.; Chavarro, J.E. Paternal physical and sedentary activities in relation to semen quality and reproductive outcomes among couples from a fertility center. Hum. Reprod. 2014, 29, 2575-2582. [CrossRef]

26. Nargund, V.H. Effects of psychological stress on male fertility. Nat. Rev. Urol. 2015, 12, 373-382. [CrossRef]

27. Durairajanayagam, D. Lifestyle causes of male infertility. Arab. J. Urol. 2018, 16, 10-20. [CrossRef]

28. Jarow, J.P.; Espeland, M.A.; Lipshultz, L.I. Evaluation of the azoospermic patient. J. Urol. 1989, 142, 62-65. [CrossRef]

29. Sigman, M.; Jarow, J.P. Endocrine evaluation of infertile men. Urology 1997, 50, 659-664. [CrossRef]

30. Urology, P.C.o.t.A.S.f.R.M.i.c.w.t.S.f.M.R.a. The management of infertility due to obstructive azoospermia. Fertil. Steril. 2008, 90, S121-S124. [CrossRef]

31. Liu, P.Y.; Handelsman, D.J. The present and future state of hormonal treatment for male infertility. Hum. Reprod. Update 2003, 9 , 9-23. [CrossRef]

32. Sussman, E.M.; Chudnovsky, A.; Niederberger, C.S. Hormonal evaluation of the infertile male: Has it evolved? Urol. Clin. North Am. 2008, 35, 147-155. [CrossRef]

33. Maya-Nuñez, G.; Zenteno, J.C.; Ulloa-Aguirre, A.; Kofman-Alfaro, S.; Mendez, J.P. A recurrent missense mutation in the KAL gene in patients with X-linked Kallmann's syndrome. J. Clin. Endocrinol. Metab. 1998, 83, 1650-1653. [CrossRef]

34. Bhasin, S.; Ma, K.; Sinha, I.; Limbo, M.; Taylor, W.E.; Salehian, B. The genetic basis of male infertility. Endocrinol. Metab. Clin. North. Am. 1998, 27, 783-805. [CrossRef]

35. Darling, D.S.; Belker, A.M. Re: The genetics of male infertility. J. Urol. 1997, 158, 550-551. [CrossRef]

36. Aiman, J.; Griffin, J.E.; Gazak, J.M.; Wilson, J.D.; MacDonald, P.C. Androgen insensitivity as a cause of infertility in otherwise normal men. N. Engl. J. Med. 1979, 300, 223-227. [CrossRef] [PubMed]

37. Kim, H.H.; Schlegel, P.N. Endocrine manipulation in male infertility. Urol. Clin. North Am. 2008, 35, 303-318. [CrossRef] [PubMed]

38. McLachlan, R.I.; O’Donnell, L.; Meachem, S.J.; Stanton, P.G.; de, K.; Pratis, K.; Robertson, D.M. Hormonal regulation of spermatogenesis in primates and man: Insights for development of the male hormonal contraceptive. J. Androl. 2002, 23, 149-162. 
39. Eggert-Kruse, W.; Schwalbach, B.; Gerhard, I.; Tilgen, W.; Runnebaum, B. Influence of serum prolactin on semen characteristics and sperm function. Int. J. Fertil. 1991, 36, 243-251. [PubMed]

40. Burrows, P.J.; Schrepferman, C.G.; Lipshultz, L.I. Comprehensive office evaluation in the new millennium. Urol. Clin. North Am. 2002, 29, 873-894. [CrossRef]

41. Siddiq, F.M.; Sigman, M. A new look at the medical management of infertility. Urol. Clin. North Am. 2002, 29, 949-963. [CrossRef]

42. Jane, J.A., Jr.; Laws, E.R., Jr. The surgical management of pituitary adenomas in a series of 3,093 patients. J. Am. Coll. Surg. 2001, 193, 651-659. [CrossRef]

43. Durairajanayagam, D.; Agarwal, A.; Ong, C. Causes, effects and molecular mechanisms of testicular heat stress. Reprod. Biomed. Online 2015, 30, 14-27. [CrossRef] [PubMed]

44. Hadziselimovic, F.; Hadziselimovic, N.O.; Demougin, P.; Oakeley, E.J. Testicular gene expression in cryptorchid boys at risk of azoospermia. Sex. Dev. 2011, 5, 49-59. [CrossRef] [PubMed]

45. Pettersson, A.; Richiardi, L.; Nordenskjold, A.; Kaijser, M.; Akre, O. Age at surgery for undescended testis and risk of testicular cancer. N. Engl. J. Med. 2007, 356. [CrossRef]

46. Visser, A.J.; Heyns, C.F. Testicular function after torsion of the spermatic cord. BJU Int. 2003, 92, 200-203. [CrossRef]

47. DaJusta, D.G.; Granberg, C.F.; Villanueva, C.; Baker, L.A. Contemporary review of testicular torsion: New concepts, emerging technologies and potential therapeutics. J. Pediatr. Urol. 2013, 9, 723-730. [CrossRef] [PubMed]

48. Mansbach, J.M.; Forbes, P.; Peters, C. Testicular torsion and risk factors for orchiectomy. Arch. Pediatr. Adolesc Med. 2005, 159, 1167-1171. [CrossRef]

49. Schuppe, H.C.; Meinhardt, A.; Allam, J.P.; Bergmann, M.; Weidner, W.; Haidl, G. Chronic orchitis: A neglected cause of male infertility? Andrologia 2008, 40, 84-91. [CrossRef]

50. Werner, C.A. Mumps orchitis and testicular atrophy; a factor in male sterility. Ann. Intern. Med. 1950, 32, 1075-1086. [CrossRef]

51. Cocuzza, M.; Alvarenga, C.; Pagani, R. The epidemiology and etiology of azoospermia. Clinics 2013, 68 (Suppl. 1), 15-26. [CrossRef]

52. Ferlin, A.; Raicu, F.; Gatta, V.; Zuccarello, D.; Palka, G.; Foresta, C. Male infertility: Role of genetic background. Reprod. Biomed. Online 2007, 14, 734-745. [CrossRef]

53. Bahadur, G.; Ralph, D. Gonadal tissue cryopreservation in boys with paediatric cancers. Hum. Reprod. 1999, 14, 11-17. [CrossRef]

54. Gandini, L.; Sgrò, P.; Lombardo, F.; Paoli, D.; Culasso, F.; Toselli, L.; Tsamatropoulos, P.; Lenzi, A. Effect of chemo- or radiotherapy on sperm parameters of testicular cancer patients. Hum. Reprod. 2006, 21, 2882-2889. [CrossRef] [PubMed]

55. Sandeman, T.F. The effects of $x$ irradiation on male human fertility. Br. J. Radiol 1966, 39, 901-907. [CrossRef]

56. Jacob, A.; Barker, H.; Goodman, A.; Holmes, J. Recovery of spermatogenesis following bone marrow transplantation. Bone Marrow Transpl. 1998, 22, 277-279. [CrossRef] [PubMed]

57. Sanders, J.E.; Hawley, J.; Levy, W.; Gooley, T.; Buckner, C.D.; Deeg, H.J.; Doney, K.; Storb, R.; Sullivan, K.; Witherspoon, R.; et al. Pregnancies following high-dose cyclophosphamide with or without high-dose busulfan or total-body irradiation and bone marrow transplantation. Blood 1996, 87, 3045-3052. [CrossRef]

58. Gbinigie, K.; Frie, K. Should chloroquine and hydroxychloroquine be used to treat COVID-19? A rapid review. BJGP Open 2020, 4. [CrossRef]

59. Kinsella, T.J.; Trivette, G.; Rowland, J.; Sorace, R.; Miller, R.; Fraass, B.; Steinberg, S.M.; Glatstein, E.; Sherins, R.J. Long-term follow-up of testicular function following radiation therapy for early-stage Hodgkin's disease. J. Clin. Oncol. 1989, 7, 718-724. [CrossRef]

60. Meistrich, M.L.; Wilson, G.; Brown, B.W.; da Cunha, M.F.; Lipshultz, L.I. Impact of cyclophosphamide on long-term reduction in sperm count in men treated with combination chemotherapy for Ewing and soft tissue sarcomas. Cancer 1992, 70, $2703-2712$. [CrossRef]

61. Meistrich, M.L.; Wilson, G.; Mathur, K.; Fuller, L.M.; Rodriguez, M.A.; McLaughlin, P.; Romaguera, J.E.; Cabanillas, F.F.; Ha, C.S.; Lipshultz, L.I.; et al. Rapid recovery of spermatogenesis after mitoxantrone, vincristine, vinblastine, and prednisone chemotherapy for Hodgkin's disease. J. Clin. Oncol. 1997, 15, 3488-3495. [CrossRef]

62. Byrne, J.; Mulvihill, J.J.; Myers, M.H.; Connelly, R.R.; Naughton, M.D.; Krauss, M.R.; Steinhorn, S.C.; Hassinger, D.D.; Austin, D.F.; Bragg, K.; et al. Effects of treatment on fertility in long-term survivors of childhood or adolescent cancer. N. Engl. J. Med. 1987, 317, 1315-1321. [CrossRef] [PubMed]

63. Okada, K.; Fujisawa, M. Recovery of Spermatogenesis Following Cancer Treatment with Cytotoxic Chemotherapy and Radiotherapy. World J. Mens Health 2019, 37, 166-174. [CrossRef] [PubMed]

64. Semet, M.; Paci, M.; Saïas-Magnan, J.; Metzler-Guillemain, C.; Boissier, R.; Lejeune, H.; Perrin, J. The impact of drugs on male fertility: A review. Andrology 2017, 5, 640-663. [CrossRef]

65. McCallum, T.; Milunsky, J.; Munarriz, R.; Carson, R.; Sadeghi-Nejad, H.; Oates, R. Unilateral renal agenesis associated with congenital bilateral absence of the vas deferens: Phenotypic findings and genetic considerations. Hum. Reprod. 2001, 16, 282-288. [CrossRef]

66. Mickle, J.; Milunsky, A.; Amos, J.A.; Oates, R.D. Congenital unilateral absence of the vas deferens: A heterogeneous disorder with two distinct subpopulations based upon aetiology and mutational status of the cystic fibrosis gene. Hum. Reprod. 1995, 10, 1728-1735. [CrossRef]

67. Claustres, M. Molecular pathology of the CFTR locus in male infertility. Reprod. Biomed. Online 2005, 10, 14-41. [CrossRef] 
68. Costabile, R.A.; Spevak, M. Characterization of patients presenting with male factor infertility in an equal access, no cost medical system. Urology 2001, 58, 1021-1024. [CrossRef]

69. Matsuda, T.; Horii, Y.; Yoshida, O. Unilateral obstruction of the vas deferens caused by childhood inguinal herniorrhaphy in male infertility patients. Fertil. Steril. 1992, 58, 609-613. [CrossRef]

70. Shin, D.; Lipshultz, L.I.; Goldstein, M.; Barmé, G.A.; Fuchs, E.F.; Nagler, H.M.; McCallum, S.W.; Niederberger, C.S.; Schoor, R.A.; Brugh, V.M., 3rd; et al. Herniorrhaphy with polypropylene mesh causing inguinal vasal obstruction: A preventable cause of obstructive azoospermia. Ann. Surg. 2005, 241, 553-558. [CrossRef]

71. Farley, S.; Barnes, R. Stenosis of ejaculatory ducts treated by endoscopic resection. J. Urol. 1973, 109, 664-666. [CrossRef]

72. Hopps, C.V.; Goldstein, M.; Schlegel, P.N. The diagnosis and treatment of the azoospermic patient in the age of intracytoplasmic sperm injection. Urol. Clin. North Am. 2002, 29, 895-911. [CrossRef]

73. Pryor, J.P.; Hendry, W.F. Ejaculatory duct obstruction in subfertile males: Analysis of 87 patients. Fertil. Steril. 1991, 56, 725-730. [CrossRef]

74. Schuster, T.G.; Ohl, D.A. Diagnosis and treatment of ejaculatory dysfunction. Urol. Clin. North Am. 2002, 29, 939-948. [CrossRef]

75. Hendry, W.F. Disorders of ejaculation: Congenital, acquired and functional. Br. J. Urol. 1998, 82, 331-341. [CrossRef]

76. López Andreu, J.A.; Fernández, P.J.; Ferrís i Tortajada, J.; Navarro, I.; Rodríguez-Ineba, A.; Antonio, P.; Muro, M.D.; Romeu, A. Persistent altered spermatogenesis in long-term childhood cancer survivors. Pediatr. Hematol. Oncol. 2000, 17, 21-30. [CrossRef]

77. Rajfer, J. TESA or TESE: Which Is Better for Sperm Extraction? Rev. Urol. 2006, 8, 171. [PubMed]

78. Ishikawa, H.; Takeshima, H. An evaluation of blood serotonin in infertile male patients. Hinyokika Kiyo 1984, 30, 1201-1205. [PubMed]

79. Kanatsu-Shinohara, M.; Toyokuni, S.; Morimoto, T.; Matsui, S.; Honjo, T.; Shinohara, T. Functional assessment of self-renewal activity of male germline stem cells following cytotoxic damage and serial transplantation. Biol. Reprod. 2003, 68, $1801-1807$. [CrossRef]

80. Ahn, J.S.; Ryu, H.-S.; Jung, S.-E.; Shin, B.-J.; Won, J.-H.; Um, T.G.; Oh, H.; Kim, S.-H.; Ryu, B.-Y. Expression profile of spermatogenesis associated genes in male germ cells during postnatal development in mice. J. Anim. Reprod. Biotechnol. 2020, 35, $289-296$. [CrossRef]

81. Han, N.R.; Park, H.J.; Lee, H.; Yun, J.I.; Choi, K.; Lee, E.; Lee, S.T. Identification of a Technique Optimized for the Isolation of Spermatogonial Stem Cells from Mouse Testes. J. Emb. Trans. 2018, 33, 327-336. [CrossRef]

82. Valli, H.; Gassei, K.; Orwig, K.E. Stem Cell Therapies for Male Infertility: Where Are We Now and Where Are We Going? In Biennial Review of Infertility: Volume 4; Carrell, D.T., Schlegel, P.N., Racowsky, C., Gianaroli, L., Eds.; Springer International Publishing: Cham, Switzerland, 2015; pp. 17-39. [CrossRef]

83. Forbes, C.M.; Flannigan, R.; Schlegel, P.N. Spermatogonial stem cell transplantation and male infertility: Current status and future directions. Arab. J. Urol. 2018, 16, 171-180. [CrossRef]

84. Geens, M.; Goossens, E.; De Block, G.; Ning, L.; Van Saen, D.; Tournaye, H. Autologous spermatogonial stem cell transplantation in man: Current obstacles for a future clinical application. Hum. Reprod. Update 2008, 14, 121-130. [CrossRef]

85. Guan, K.; Nayernia, K.; Maier, L.S.; Wagner, S.; Dressel, R.; Lee, J.H.; Nolte, J.; Wolf, F.; Li, M.; Engel, W.; et al. Pluripotency of spermatogonial stem cells from adult mouse testis. Nature 2006, 440, 1199-1203. [CrossRef] [PubMed]

86. Kanatsu-Shinohara, M.; Takehashi, M.; Shinohara, T. Brief history, pitfalls, and prospects of mammalian spermatogonial stem cell research. Cold Spring Harb. Symp. Quant. Biol. 2008, 73, 17-23. [CrossRef] [PubMed]

87. Seandel, M.; James, D.; Shmelkov, S.V.; Falciatori, I.; Kim, J.; Chavala, S.; Scherr, D.S.; Zhang, F.; Torres, R.; Gale, N.W.; et al. Generation of functional multipotent adult stem cells from GPR125+ germline progenitors. Nature 2007, 449, 346-350. [CrossRef]

88. Phillips, B.T.; Gassei, K.; Orwig, K.E. Spermatogonial stem cell regulation and spermatogenesis. Philos. Trans. R Soc. Lond. B Biol. Sci. 2010, 365, 1663-1678. [CrossRef] [PubMed]

89. Park, J.E.; Park, M.H.; Kim, M.S.; Yun, J.I.; Choi, J.H.; Lee, E.; Lee, S.T. Development of a Three-dimensional Hydrogel System for the Maintenance of Porcine Spermatogonial Stem Cell Self-renewal. J. Emb. Trans. 2017, 32, 343-351. [CrossRef]

90. Freeman, B. The active migration of germ cells in the embryos of mice and men is a myth. Reproduction 2003, 125, 635-643. [CrossRef] [PubMed]

91. Mollgard, K.; Jespersen, A.; Lutterodt, M.C.; Yding Andersen, C.; Hoyer, P.E.; Byskov, A.G. Human primordial germ cells migrate along nerve fibers and Schwann cells from the dorsal hind gut mesentery to the gonadal ridge. Mol. Hum. Reprod. 2010, 16, 621-631. [CrossRef]

92. Matte, R.; Sasaki, M. Autoradiographic evidence of human male germ-cell differentiation in vitro. Cytologia 1971, 36, 298-303. [CrossRef]

93. Cremades, N.; Bernabeu, R.; Barros, A.; Sousa, M. In-vitro maturation of round spermatids using co-culture on Vero cells. Hum. Reprod. 1999, 14, 1287-1293. [CrossRef] [PubMed]

94. Tanaka, A.; Nagayoshi, M.; Awata, S.; Mawatari, Y.; Tanaka, I.; Kusunoki, H. Completion of meiosis in human primary spermatocytes through in vitro coculture with Vero cells. Fertil. Steril. 2003, 79 (Suppl 1), 795-801. [CrossRef]

95. De Michele, F.; Poels, J.; Vermeulen, M.; Ambroise, J.; Gruson, D.; Guiot, Y.; Wyns, C. Haploid Germ Cells Generated in Organotypic Culture of Testicular Tissue from Prepubertal Boys. Front. Physiol. 2018, 9, 1413. [CrossRef] [PubMed]

96. Devolder, K. Complicity in stem cell research: The case of induced pluripotent stem cells. Hum. Reprod. 2010, 25, 2175-2180. [CrossRef] [PubMed] 
97. Clermont, Y. Kinetics of spermatogenesis in mammals: Seminiferous epithelium cycle and spermatogonial renewal. Physiol. Rev. 1972, 52, 198-236. [CrossRef]

98. Valli, H.; Phillips, B.T.; Orwig, K.E.; Gassei, K.; Nagano, M.C. Knobil and Neill's Physiology of Reproduction, 4th ed.; Spermatogonial Stem Cells and Spermatogenesis; Academic Press: San Diego, CA, USA, 2015; pp. 595-635.

99. Roosen-Runge, E.C. Quantitative studies on spermatogenesis in the albino rat. II. The duration of spermatogenesis and some effects of colchicine. Am. J. Anat. 1951, 88, 163-176. [CrossRef] [PubMed]

100. Clermont, Y.; Leblond, C.P. Renewal of spermatogonia in the rat. Am. J. Anat. 1953, 93, 475-501. [CrossRef]

101. Huckins, C. The spermatogonial stem cell population in adult rats. I. Their morphology, proliferation and maturation. Anat. Rec. 1971, 169, 533-557. [CrossRef]

102. Oakberg, E.F. Spermatogonial stem-cell renewal in the mouse. Anat. Rec. 1971, 169, 515-531. [CrossRef] [PubMed]

103. Yoshida, S.; Nabeshima, Y.; Nakagawa, T. Stem cell heterogeneity: Actual and potential stem cell compartments in mouse spermatogenesis. Ann. N. Y. Acad. Sci. 2007, 1120, 47-58. [CrossRef]

104. Morimoto, H.; Kanatsu-Shinohara, M.; Takashima, S.; Chuma, S.; Nakatsuji, N.; Takehashi, M.; Shinohara, T. Phenotypic plasticity of mouse spermatogonial stem cells. PLoS ONE 2009, 4, e7909. [CrossRef] [PubMed]

105. Huckins, C. The spermatogonial stem cell population in adult rats. II. A radioautographic analysis of their cell cycle properties. Cell Tissue Kinet 1971, 4, 313-334. [CrossRef] [PubMed]

106. Oakberg, E.F. A description of spermiogenesis in the mouse and its use in analysis of the cycle of the seminiferous epithelium and germ cell renewal. Am. J. Anat. 1956, 99, 391-413. [CrossRef] [PubMed]

107. Waheeb, R.; Hofmann, M.C. Human spermatogonial stem cells: A possible origin for spermatocytic seminoma. Int. J. Androl. 2011, 34, e296-e305. [CrossRef]

108. Clermont, Y.; Bustos-Obregon, E. Re-examination of spermatogonial renewal in the rat by means of seminiferous tubules mounted "in toto". Am. J. Anat. 1968, 122, 237-247. [CrossRef]

109. Dym, M.; Clermont, Y. Role of spermatogonia in the repair of the seminiferous epithelium following x-irradiation of the rat testis. Am. J. Anat. 1970, 128, 265-282. [CrossRef]

110. Clermont, Y.; Antar, M. Duration of the cycle of the seminiferous epithelium and the spermatogonial renewal in the monkey Macaca arctoides. Am. J. Anat. 1973, 136, 153-165. [CrossRef]

111. Kostereva, N.; Hofmann, M.C. Regulation of the Spermatogonial Stem Cell Niche. Reprod. Domest. Anim. 2008, 43, 386-392. [CrossRef]

112. Dadoune, J.P. New insights into male gametogenesis: What about the spermatogonial stem cell niche? Folia. Histochem. Cytobiol. 2007, 45, 141-147.

113. De Rooij, D.G. The spermatogonial stem cell niche. Microsc. Res. Tech. 2009, 72, 580-585. [CrossRef] [PubMed]

114. De Rooij, D.G. Sertoli Cell Biology, 2nd ed.; The Spermatogonial Stem Cell Niche in Mammals; Academic Press: San Diego, CA, USA, 2015; pp. 99-121.

115. Tung, P.S.; Skinner, M.K.; Fritz, I.B. Cooperativity between Sertoli cells and peritubular myoid cells in the formation of the basal lamina in the seminiferous tubule. Ann. N. Y. Acad. Sci. 1984, 438, 435-446. [CrossRef] [PubMed]

116. Griswold, M.D. The central role of Sertoli cells in spermatogenesis. Semin. Cell Dev. Biol. 1998, 9, 411-416. [CrossRef]

117. Kanatsu-Shinohara, M.; Ogonuki, N.; Inoue, K.; Ogura, A.; Toyokuni, S.; Shinohara, T. Restoration of fertility in infertile mice by transplantation of cryopreserved male germline stem cells. Hum. Reprod. 2003, 18, 2660-2667. [CrossRef]

118. Kanatsu-Shinohara, M.; Miki, H.; Inoue, K.; Ogonuki, N.; Toyokuni, S.; Ogura, A.; Shinohara, T. Germline niche transplantation restores fertility in infertile mice. Hum. Reprod. 2005, 20, 2376-2382. [CrossRef] [PubMed]

119. Cheng, C.Y.; Mruk, D.D. Cell junction dynamics in the testis: Sertoli-germ cell interactions and male contraceptive development. Physiol. Rev. 2002, 82, 825-874. [CrossRef]

120. Brinster, R.L.; Avarbock, M.R. Germline transmission of donor haplotype following spermatogonial transplantation. Proc. Natl. Acad. Sci. USA 1994, 91, 11303-11307. [CrossRef] [PubMed]

121. Gul, M.; Hildorf, S.; Dong, L.; Thorup, J.; Hoffmann, E.R.; Jensen, C.F.S.; Sønksen, J.; Cortes, D.; Fedder, J.; Andersen, C.Y.; et al. Review of injection techniques for spermatogonial stem cell transplantation. Hum. Reprod. Update 2020, 26, 368-391. [CrossRef] [PubMed]

122. Matzuk, M.M.; Lamb, D.J. The biology of infertility: Research advances and clinical challenges. Nat. Med. 2008, 14, 1197-1213. [CrossRef] [PubMed]

123. Ginsberg, J.P.; Carlson, C.A.; Lin, K.; Hobbie, W.L.; Wigo, E.; Wu, X.; Brinster, R.L.; Kolon, T.F. An experimental protocol for fertility preservation in prepubertal boys recently diagnosed with cancer: A report of acceptability and safety. Hum. Reprod. 2010, 25, 37-41. [CrossRef]

124. Lim, J.J.; Sung, S.Y.; Kim, H.J.; Song, S.H.; Hong, J.Y.; Yoon, T.K.; Kim, J.K.; Kim, K.S.; Lee, D.R. Long-term proliferation and characterization of human spermatogonial stem cells obtained from obstructive and non-obstructive azoospermia under exogenous feeder-free culture conditions. Cell Prolif. 2010, 43, 405-417. [CrossRef]

125. Oatley, J. Cryopreserving and Thawing Spermatogonial Stem Cells. Cold Spring Harb. Protoc. 2017, 2017 , pdb.prot094219. [CrossRef] [PubMed]

126. Goodyear, S.; Brinster, R. Isolation of the Spermatogonial Stem Cell-Containing Fraction from Testes. Cold Spring Harb. Protoc. 2017, 2017, pdb.prot094185. [CrossRef] [PubMed] 
127. Kubota, H.; Brinster, R.L. Culture of rodent spermatogonial stem cells, male germline stem cells of the postnatal animal. Methods Cell Biol. 2008, 86, 59-84. [CrossRef]

128. de Siqueira-Silva, D.H.; Dos Santos Silva, A.P.; da Silva Costa, R.; Senhorini, J.A.; Ninhaus-Silveira, A.; Veríssimo-Silveira, R. Preliminary study on testicular germ cell isolation and transplantation in an endangered endemic species Brycon orbignyanus (Characiformes: Characidae). Fish. Physiol. Biochem. 2019, 3, 767-776. [CrossRef]

129. Goodyear, S.; Brinster, R. Culture and Expansion of Primary Undifferentiated Spermatogonial Stem Cells. Cold Spring Harb. Protoc. 2017, 2017, pdb.prot094193. [CrossRef]

130. Liu, S.; Tang, Z.; Xiong, T.; Tang, W. Isolation and characterization of human spermatogonial stem cells. Reprod. Biol. Endocrinol. 2011, 9, 141. [CrossRef]

131. Mohaqiq, M.; Movahedin, M.; Mazaheri, Z.; Amirjannati, N. In vitro transplantation of spermatogonial stem cells isolated from human frozen-thawed testis tissue can induce spermatogenesis under 3-dimensional tissue culture conditions. Biol. Res. 2019, 52. [CrossRef] [PubMed]

132. Takahashi, K.; Yamanaka, S. Induction of pluripotent stem cells from mouse embryonic and adult fibroblast cultures by defined factors. Cell 2006, 126, 663-676. [CrossRef]

133. Martin, L.A.; Seandel, M. Propagation of Adult SSCs: From Mouse to Human. Biomed. Res. Int. 2013, 2013, 1-9. [CrossRef]

134. Voigt, A.L.; Thiageswaran, S.; de Lima e Martins Lara, N.; Dobrinski, I. Metabolic Requirements for Spermatogonial Stem Cell Establishment and Maintenance In Vivo and In Vitro. Int. J. Mol. Sci. 2021, 22, 1998. [CrossRef] [PubMed]

135. Choi, N.Y.; Park, Y.S.; Ryu, J.-S.; Lee, H.J.; Araúzo-Bravo, M.J.; Ko, K.; Han, D.W.; Schöler, H.R.; Ko, K. A Novel Feeder-Free Culture System for Expansion of Mouse Spermatogonial Stem Cells. Mol. Cells 2014, 37, 473-479. [CrossRef]

136. Yang, Y.; Lin, Q.; Zhou, C.; Li, Q.; Li, Z.; Cao, Z.; Liang, J.; Li, H.; Mei, J.; Zhang, Q.; et al. A Testis-Derived Hydrogel as an Efficient Feeder-Free Culture Platform to Promote Mouse Spermatogonial Stem Cell Proliferation and Differentiation. Front. Cell Dev. Biol. 2020, 8. [CrossRef] [PubMed]

137. Guo, Y.; Liu, L.; Sun, M.; Hai, Y.; Li, Z.; He, Z. Expansion and long-term culture of human spermatogonial stem cells via the activation of SMAD3 and AKT pathways. Exp. Biol. Med. 2015, 240, 1112-1122. [CrossRef]

138. He, Z.; Kokkinaki, M.; Jiang, J.; Dobrinski, I.; Dym, M. Isolation, Characterization, and Culture of Human Spermatogonia1. Biol. Reprod. 2010, 82, 363-372. [CrossRef]

139. Hou, J.; Niu, M.; Liu, L.; Zhu, Z.; Wang, X.; Sun, M.; Yuan, Q.; Yang, S.; Zeng, W.; Liu, Y.; et al. Establishment and Characterization of Human Germline Stem Cell Line with Unlimited Proliferation Potentials and no Tumor Formation. Sci. Rep. 2015, 5. [CrossRef]

140. Chen, W.; Cui, Y.; Liu, B.; Li, C.; Du, L.; Tang, R.; Qin, L.; Jiang, Y.; Li, J.; Yu, X.; et al. Hsa-miR-1908-3p Mediates the Self-Renewal and Apoptosis of Human Spermatogonial Stem Cells via Targeting KLF2. Mol. Ther. Nucleic Acids 2020, 20, 788-800. [CrossRef]

141. Nagano, M.; Patrizio, P.; Brinster, R.L. Long-term survival of human spermatogonial stem cells in mouse testes. Fertil. Steril. 2002, 78, 1225-1233. [CrossRef]

142. Mohaqiq, M.; Movahedin, M.; Mazaheri, Z.; Amirjannati, N. Successful Human Spermatogonial Stem Cells Homing in Recipient Mouse Testis after In Vitro Transplantation and Organ Culture. Cell J. 2019, 20, 513-520. [CrossRef] [PubMed]

143. Kim, Y.; Turner, D.; Nelson, J.; Dobrinski, I.; McEntee, M.; Travis, A.J. Production of donor-derived sperm after spermatogonial stem cell transplantation in the dog. Reproduction 2008, 136, 823-831. [CrossRef]

144. Shetty, G.; Mitchell, J.M.; Lam, T.N.A.; Phan, T.T.; Zhang, J.; Tailor, R.C.; Peters, K.A.; Penedo, M.C.; Hanna, C.B.; Clark, A.T.; et al Postpubertal Spermatogonial Stem Cell Transplantation Restores Functional Sperm Production in Rhesus Monkeys Irradiated Before and After Puberty. Andrology 2021. [CrossRef]

145. Eildermann, K.; Gromoll, J.; Behr, R. Misleading and reliable markers to differentiate between primate testis-derived multipotent stromal cells and spermatogonia in culture. Hum. Reprod. 2012, 27, 1754-1767. [CrossRef]

146. Kim, Y.H.; Kang, H.G.; Kim, B.J.; Jung, S.E.; Karmakar, P.C.; Kim, S.M.; Hwang, S.; Ryu, B.Y. Enrichment and In Vitro Culture of Spermatogonial Stem Cells from Pre-Pubertal Monkey Testes. Tissue Eng Regen Med. 2017, 14, 557-566. [CrossRef]

147. Trowell, O.A. The culture of mature organs in a synthetic medium. Exp. Cell Res. 1959, 16, 118-147. [CrossRef]

148. Steinberger, E.; Steinberger, A.; Perloff, W.H. Initiation of spermatogenesis in vitro. Endocrinology 1964, 74, 788-792. [CrossRef]

149. Steinberger, E.; Steinberger, A.; Perloff, W.H. Studies on growth in organ culture of testicular tissue from rats of various ages. Anat. Rec. 1964, 148, 581-589. [CrossRef]

150. Boitani, C.; Politi, M.G.; Menna, T. Spermatogonial cell proliferation in organ culture of immature rat testis. Biol. Reprod. 1993, 48, 761-767. [CrossRef] [PubMed]

151. Suzuki, S.; Sato, K. The fertilising ability of spermatogenic cells derived from cultured mouse immature testicular tissue. Zygote 2003, 11, 307-316. [CrossRef]

152. Sato, T.; Katagiri, K.; Gohbara, A.; Inoue, K.; Ogonuki, N.; Ogura, A.; Kubota, Y.; Ogawa, T. In vitro production of functional sperm in cultured neonatal mouse testes. Nature 2011, 471, 504-507. [CrossRef] [PubMed]

153. Sato, T.; Yokonishi, T.; Komeya, M.; Katagiri, K.; Kubota, Y.; Matoba, S.; Ogonuki, N.; Ogura, A.; Yoshida, S.; Ogawa, T. Testis tissue explantation cures spermatogenic failure in c-Kit ligand mutant mice. Proc. Natl. Acad. Sci. USA 2012, 109, 16934-16938. [CrossRef] [PubMed]

154. Yokonishi, T.; Sato, T.; Komeya, M.; Katagiri, K.; Kubota, Y.; Nakabayashi, K.; Hata, K.; Inoue, K.; Ogonuki, N.; Ogura, A.; et al. Offspring production with sperm grown in vitro from cryopreserved testis tissues. Nat. Commun. 2014, 5, 4320. [CrossRef] [PubMed] 
155. Zhao, H.; Nie, J.; Zhu, X.; Lu, Y.; Liang, X.; Xu, H.; Yang, X.; Zhang, Y.; Lu, K.; Lu, S. In vitro differentiation of spermatogonial stem cells using testicular cells from Guangxi Bama mini-pig. J Vet Sci. 2018, 19, 592-599. [CrossRef]

156. Ibtisham, F.; Honaramooz, A. Spermatogonial Stem Cells for In Vitro Spermatogenesis and In Vivo Restoration of Fertility. Cells 2020, 9, 745. [CrossRef]

157. Dumont, L.; Oblette, A.; Rondanino, C.; Jumeau, F.; Bironneau, A.; Liot, D.; Duchesne, V.; Wils, J.; Rives, N. Vitamin A prevents round spermatid nuclear damage and promotes the production of motile sperm during in vitro maturation of vitrified pre-pubertal mouse testicular tissue. Mol. Hum. Reprod. 2016, 22, 819-832. [CrossRef]

158. Matsumura, T.; Sato, T.; Abe, T.; Sanjo, H.; Katagiri, K.; Kimura, H.; Fujii, T.; Tanaka, H.; Hirabayashi, M.; Ogawa, T. Rat in vitro spermatogenesis promoted by chemical supplementations and oxygen-tension control. Sci. Rep. 2021, 11, 3458. [CrossRef] [PubMed]

159. Nasimi, M.; Jorsaraei, S.G.A.; Fattahi, E.; Tabari, M.G.; Neyshaburi, E.Z. SCF Improves In Vitro Differentiation of SSCs Through Transcriptionally Up-regulating PRTM1, STRA8, c-KIT, PIWIL2, and OCT4 Genes. Reprod. Sci. 2021, 28, 963-972. [CrossRef]

160. Arkoun, B.; Galas, L.; Dumont, L.; Rives, A.; Saulnier, J.; Delessard, M.; Rondanino, C.; Rives, N. Vitamin E but Not GSH Decreases Reactive Oxygen Species Accumulation and Enhances Sperm Production during In Vitro Maturation of Frozen-Thawed Prepubertal Mouse Testicular Tissue. Int. J. Mol. Sci. 2019, 20, 5380. [CrossRef] [PubMed]

161. Kurkure, P.; Prasad, M.; Dhamankar, V.; Bakshi, G. Very small embryonic-like stem cells (VSELs) detected in azoospermic testicular biopsies of adult survivors of childhood cancer. Reprod. Biol. Endocrinol. 2015, 13, 122. [CrossRef] [PubMed]

162. Wyns, C.; Kanbar, M.; Giudice, M.G.; Poels, J. Fertility preservation for prepubertal boys: Lessons learned from the past and update on remaining challenges towards clinical translation. Hum. Reprod. Update 2021, 27, 433-459. [CrossRef] [PubMed]

163. Xu, H.; Yang, M.; Tian, R.; Wang, Y.; Liu, L.; Zhu, Z.; Yang, S.; Yuan, Q.; Niu, M.; Yao, C.; et al. Derivation and propagation of spermatogonial stem cells from human pluripotent cells. Stem Cell Res. Ther. 2020, 11. [CrossRef] [PubMed]

164. Cakici, C.; Buyrukcu, B.; Duruksu, G.; Haliloglu, A.H.; Aksoy, A.; Isık, A.; Uludag, O.; Ustun, H.; Subası, C.; Karaoz, E. Recovery of fertility in azoospermia rats after injection of adipose-tissue-derived mesenchymal stem cells: The sperm generation. Biomed Res. Int. 2013, 2013, 529589. [CrossRef] [PubMed]

165. Zhang, D.; Liu, X.; Peng, J.; He, D.; Lin, T.; Zhu, J.; Li, X.; Zhang, Y.; Wei, G. Potential spermatogenesis recovery with bone marrow mesenchymal stem cells in an azoospermic rat model. Int. J. Mol. Sci. 2014, 15, 13151-13165. [CrossRef] [PubMed]

166. Kadam, P.; Ntemou, E.; Onofre, J.; Van Saen, D.; Goossens, E. Does co-transplantation of mesenchymal and spermatogonial stem cells improve reproductive efficiency and safety in mice? Stem Cell Res. Ther. 2019, 10. [CrossRef] [PubMed] 